\title{
TRENDS IN RESTRUCTURING OF BULGARIAN AGRICULTURE
}

\author{
N. Kostadinova* \\ Department of Management, Faculty of Economics, Trakia University, Stara Zagora, Bulgaria
}

\begin{abstract}
Bulgarian agriculture has been operating for ten years on the Common European market and under the Common agricultural policy (CAP). This period is characterized by dynamic structural changes in the agricultural sector.

The process of restructuring the farms is associated with a reduction in their numbers, but an increase in their average size, a deepening of the unilateral production structure with a predominant share of extensive crops, an increase in the level of specialization and concentration of production. The purpose of this paper is to examine the trends in the restructuring of Bulgarian agriculture under the influence of the EU CAP. The following tasks are fulfilled in order to achieve the objective: to analyze the state of agriculture in Bulgaria; to reveal key factors and trends in structural changes in agriculture.

The methods used to solve these tasks and achieve the goal are analysis and synthesis, axiomatic, method of statistical groupings and comparison, induction and deduction, structural - functional approach.

Expectations from the study are that Bulgarian agriculture has deepened its dualist structure - on the one hand - a small number of large farms specializing in extensive crops and on the other - many small farms producing mainly for their own consumption.
\end{abstract}

Key words: agricultural holdings, agricultural policy, structural changes

\section{INTRODUCTION}

As a result of the implementation of $\mathrm{EU}$ Common Agricultural Policy (CAP) restructuring processes aiming to reduce the farm number and their consolidation are taking place in Bulgarian agriculture. A dual agrarian structure is being made - on the one hand a few large-scale farms, specialized mainly in the production of cereal and technical crops, and on the other hand -a lot of small-scale farms, specialized in animal breeding, fruit and vegetable growing, satisfying their own needs.

The goal of the present study is to investigate the trends in restructuring of Bulgarian agriculture under the influence of the EU CAP. To achieve this goal the following tasks are accomplished: analysis of agriculture in Bulgaria; discussion of the main factors and trends of the structural changes in agriculture.

\section{MATERIAL AND METHODS}

Methods, used for the solution to the tasks and achieving the goals are analysis and synthesis, the axiomatic method, the method of the

\footnotetext{
*Correspondence to: Nadka Kostadinova, Department of Management, Faculty of Economics, Trakia University, Stara Zagora, Bulgaria, Email: nadya_kostadinova@yahoo.com,Tel: +359-42699-416
}

statistical groupings and comparison, induction and deduction, a structural-functional approach.

\section{RESULTS AND DISCUSSION}

The structure of agriculture is a sequence to the changes of the economic, social, political and technological macro environment. These changes are an integral part of contemporary life and determine different points of view in the estimation of the structural changes. They are traditionally identified with changes of the volume and type of the different agricultural activities. The scale of the farm (physical and economic), product realization, financial situation, property, technology, characteristics of the labor force, institutional arrangements have an impact on the structural changes.

In economic literature, related to structural changes there is a consensus among authors concerning the factors which cause these changes. Structural changes have a complex character. However, there is not an independent and exhaustive theory, integrating the leading factors and their interactions into a whole system.

The 2004-2015 period for Bulgarian agriculture is characterized by dynamic 
structural changes of the farms. A stable trend towards a threefold decrease in the farm numbers - from 665,5 thousand in 2004 to 254,1 thousand for 2015 (MAF, Agrostatistics), with the process of reduction in the farm numbers going on more intensively after the accession of Bulgaria to the EU and the implementation of the CAP.

The market -oriented and economically viable agriculture requires the presence of consolidated land for use and possession. The farm land market creates conditions for the realization of the property rights on the agricultural land and secures a rational and efficient land use. The functioning of the land market is related to the particular role of the land as a main and fundamental resource in agriculture, an important factor of production and development of the land relations, expressing relations between the citizens, legal entities, local bodies of self-government and bodies of state power concerning possession, use and disposition of the land.

For the 2000-2015 period the farm land market in Bulgaria is becoming more and more active and dynamic. A growth in the parameters studied is reported each year. Until 2004 the market was weak and unattractive, there was a big supply of farm land and barely any demand. This resulted in few transactions and the average market price reached 140 BGN/dekare.

The farm land market became more active for the 2004-2006 period and the number of the transactions increased by $40 \%$ on average annually. The market price increased by $25 \%$ and reached $175 \mathrm{BGN} /$ dekare.

For the 2007-2013 period, when the country was a full member of the EU, the farm land market was reported to be extremely active. The financial support in the CAP framework, given on the basis of arable land, increased the interest in buying land. For the 2007-2009 period 3.5 million dekares of land was sold, and the transactions made were almost 374000 .The average market price reached 297 BGN/dekare at the end of this period.

Compared with 2014, in 2015 the average price of one dekare farm land reached 732 BGN, an increase by 7\% was reported. In 2014 the average price of one dekare farm land reached $684 \mathrm{BGN}$, which is by $15.2 \%$ more than that in 2013. In 2014 the vineyards' price increased by $41.4 \%$ compared to that of 2013 . The fields' price rose by $14.0 \%$, that of orchards - by $1.6 \%$, and the price of the grasslands - by $24.2 \%$.

In the last years the land has been converted from a barely liquid asset into a sought product and its price has risen in times.

For the $2004-2015$ period structural changes are characterized by different intensity and are related to the decrease in the farm number of all organization forms except for the commercial companies (MAF, Agrostatistics):

- Processes in the groups of farms, owned by natural persons, have been the most dynamic with a trend in reducing of their number, due mainly to the terminating of the activity of the small farms. For the period analyzed here the decrease in the farm number was by $63 \%$, but an increase by $39 \%$ in the land, cultivated by them, was registered;

- There is also a trend in reducing the number of cooperatives. After the accession of Bulgaria to the EU the introduction of direct payments led to the increase in the land price and the rent. At a lower level of efficient production some of the cooperatives did not meet the expectations of the land owners about the rent increase. The reasons for the termination of the activities of some cooperatives are consequences from the following: some owners took back their land in order to sell it or to give it to commercial companies for a higher rent. From 1973 in 2004 the number of the cooperatives fell to 811 for 2015 , which represents a decrease by $59 \%$, related to the $50 \%$ reduction of the land cultivated by them;

-a considerable increase in the number of the commercial societies - it rose to 4323 in 2015 , which means a threefold increase, accompanied by a threefold increase in the usable agricultural area (UAA).

- Against the backdrop of ongoing intensive processes in other organizational forms in the ET farm group the change is smaller towards the reduction of their number and the rise of the UAA, cultivated by them.

Data illustrate that the bipolar model of the organizational and economic structure in the agriculture is becoming sharper and the difference between the sizes of agricultural holdings under legal status is deepening.

The ratio between plant growing to animal breeding production is changing dynamically (an important index for the intensification of the agriculture) - from 45\%: 55\% in 1989 to 51\%: $49 \%$ in 1999 and about 70\%: $30 \%$ in 2015. 
Extensive crops dominate in our plant growing with the wheat at the top, followed by the corn and barley. This very different structure represents the influence of the CAP on Bulgarian agriculture. The financial aid by the European funds for supporting this branch has been successfully implemented by the production of cereal and technical crops.

The growth rate is the best expressed by the wheat, a principal cereal crop in our country. After 2008 an increase in corn production has been observed. In spite of some fluctuations the high growth in the general production of the main cereal crops after the CAP implementation in Bulgaria has remained unchanged.

The economic results in the cereal production sector besides being functions of the natural and climatic conditions and of production and technological factors, depend also on the production Buying prices of soft wheat, produced in Bulgaria, gravitate around the minimal buying price in the EU-28.The analysis shows the determining importance of the wheat in the final economic results from the plant growing. In this respect the buying price is a factor, whose importance for the competitiveness has been underestimated. The price is decisive for the final economic results, achieved by the producers. But the levers for influence on the pricing are, to a great extent, an object of national and regional policy. The market sustainability is a determining factor.
After 2007 sugar beet, flax, hemp, sorghum, cotton and rye have barely been cultivated. The areas with perennials, such as apples, cherries, apricots, have been considerably reduced. Trends in the legume group have been strongly negative - particularly in white beans, peas and lentils. Bulgaria has become an ex-exporter and importer of almost all vegetables. The potato production is continuing to decreasing. The interest in restoration of fruit growing is not big enough. A positive trend has been observed in the viticulture- wine-producing companies began planting new vineyards of certain varieties to provide a quality raw material.

Some negative trends have also been observed in Bulgarian animal breeding.

This characteristic feature of the national agricultural structure -the duality- dominates the livestock breeding too.

The average number of animals, raised in the farms in 2004, shows that the small-scale production characterizes all animal groups with the average cattle number on a farm being 3 , of sheep-7, of pigs-5, etc. For 2015 an increase in the average farm animal number was reported in all groups. Data for 2015 show that the average cattle number on the farms rose to 13 , sheep - to 35 , pigs- to 41 and poultry - to 173. (Table 1)

Table 1. Average number of animals, raised on a farm

\begin{tabular}{|l|l|l|l|l|}
\hline $\begin{array}{l}\text { Group of } \\
\text { animals }\end{array}$ & $\mathbf{2 0 0 4}$ & $\mathbf{2 0 1 4}$ & $\mathbf{2 0 1 5}$ & $\begin{array}{l}\text { Change } \\
\mathbf{2 0 1 4 / 2 0 1 5 ,} \%\end{array}$ \\
\hline Cattle & 3 & 10,3 & 13 & 126,4 \\
\hline Sheep & 7 & 28,5 & 35,3 & 123,8 \\
\hline Goats & 3 & 9,3 & 11,2 & 120,3 \\
\hline Pigs & 5 & 24,8 & 41,4 & 166,9 \\
\hline Poultry & 44 & 150 & 173 & 115,3 \\
\hline Poultry & 44 & 150 & 173 & 115,3 \\
\hline
\end{tabular}

Source: MAF, Agristatistics

The sub branches of animal breeding have economic and organization differences as a result of the animal biological characteristics, the development and the different relevance of scientific and technical achievements.

Dairy farming is dominated by small, selfsustaining farms. Most farms determine themselves as small and this is relevant to $98 \%$ of the cow and bull farms, 97\% of the sheep farms and $99 \%$ of the goat farms. As regards the farm structure a positive signal is given by the gradual increase in the bigger-farm number at the expense of the small, self-sufficient households. An example of this is the increase in the cow farms, raising more than 20 cows. Such a consolidation has also been observed in the other animal breeding sub branches, which, however, cannot stop the continuing decrease in the number of animals raised.

The main factors for this continuing contraction in dairy farming are hidden in the economic difficulties of owners to realize their production. The unattractive labor conditions, along with the decline of Bulgarian villages 
and the aging of the population there represent the other main reason for the reduction of the cattle herds and small farm animal (SFA) bands.

Data in Table 2 show that for the 2004-2015 period the number of cattle and SFA decreased, the most striking being the shortening of the SFA number where the decrease was 800,000 . This is largely due to the decrease in the number of goats which reached almost $1,000,000$ at the beginning of this millennium, and as of 2015 their number was reduced to below 300,000 .

At a slower pace is the decrease in cattle breeding where the decrease is about $20 \%$ for the mentioned period.

Table 2. Number of animals - Cattle and SFA in thousands

\begin{tabular}{|l|l|l|l|l|l|}
\hline $\begin{array}{l}\text { Type of } \\
\text { animals }\end{array}$ & $\mathbf{2 0 0 4}$ & $\mathbf{2 0 0 7}$ & $\mathbf{2 0 1 0}$ & $\mathbf{2 0 1 4}$ & $\mathbf{2 0 1 5}$ \\
\hline Cattle & 671,6 & 602,1 & 544,5 & 552,8 & 550,2 \\
\hline $\begin{array}{l}\text { Incl.dairy } \\
\text { cows }\end{array}$ & 368,7 & 335,9 & 308,2 & 295,3 & 276,2 \\
\hline $\begin{array}{l}\text { Sheep } \\
\text { and goats }\end{array}$ & 2410,6 & 2021,9 & 1724,3 & 1628 & 1608,8 \\
\hline $\begin{array}{l}\text { Incl.sheep } \\
\text { and does }\end{array}$ & 1929,7 & 1639,4 & 1371,0 & 1336,7 & 1244,4 \\
\hline
\end{tabular}

Source: MAF, Agristatistics

The main reduction in the bovine livestock population is due to a reduction in the number of animals kept on small farms with up to 5 cows.

They either reduce their number or completely cease their activities

Since 2007 Bulgaria, which used to be a net exporter of milk and dairy raw materials, has become a net importer, with milk being bought from dairies over the last 3-4 years on the decline. The reasons for this are, on the one hand, the structure of production - a significant percentage of small, self-sufficient farms not adapted to current market requirements and, on the other, worsening competitiveness of the dairy sector within European borders.
The primary requirement of farms, especially in cattle breeding, is their modernization to meet the requirements for the production and obtaining of safe and quality milk. Investment and grant finance is of the utmost importance in order to increase the competitiveness of the branch.

Since 2000, pig production has been steadily declining in the number of animals that has not been overtaken since our accession to the EU. If the average annual number of pigs is taken for the period 2000-2006, for the period 20072014 their average annual number represents $66.4 \%$ of the base, including of sows $-60.4 \%$, with the decrease in the number continuing in 2016 (Table 3)

Table 3. Number of pigs in thousands

\begin{tabular}{|l|l|l|l|l|}
\hline & $\begin{array}{l}\text { 2000-2006. } \\
\text { On average }\end{array}$ & $\begin{array}{l}\text { 2007-2014. } \\
\text { On average }\end{array}$ & $\begin{array}{l}\mathbf{2 0 0 7 - 2 0 1 4 /} \\
\mathbf{2 0 0 0 - 2 0 0 6 .}\end{array}$ & $\mathbf{2 0 1 6}$ \\
\hline $\begin{array}{l}\text { Pigs, } \\
\text { total }\end{array}$ & 1031,0 & 684,5 & $66,4 \%$ & 620,0 \\
\hline $\begin{array}{l}\text { Includin } \\
\text { g sows }\end{array}$ & 92,0 & 55,5 & $60,4 \%$ & 60,0 \\
\hline
\end{tabular}

Source: Statistical Yearbook and own calculations

* Data as of 01.11

Restructuring in pig production has not yet ended and has undergone changes and fluctuations over the past few years. There is a slight tendency for the past few years to stabilize the number of pigs, while, simultaneously, production is concentrated in fewer and larger farms. Large industrial farms, which are competitive and profitable, remain on the market. The most intensive livestock sector is poultry farming. Since 2007 not only the internal market, but, to a large extent, factors relating to the requirements of the common European market for the application of new technologies, prices and quality, food safety, animal welfare, the protection of the environment have been important for its development. 
Between 2000 and 2006, the number of birds gradually and surely increased to reach $20,156,000$ units in 2006 and then began to decline again, reaching $14,656,000$ in 2011 . This downward trend is overcome in 2012, when the total number of birds increases, compared to the previous year, albeit only by $4.1 \%$, reaching 15 260 thousand, to decrease in 2013 to 13213 thousand, or by $13.4 \%$. In 2015 the total number of birds is 15.6 million, which is $6.8 \%$ more than in 2014. The number of laying hens and briars is 6980 thousand, of which 4.8 million are commodity 1.1 million pieces are breeding laying hens and so many are the immature laying hens. (MAF, Agrostatistics).

Over the last few years, poultry farming has been undergoing a process of farm reconstruction and modernization, as well as establishing systems that ensure welfare in poultry farming, complying with EU requirements. This leads to a large extent to changes in the production and product structure of the sector.

The new programming period for the CAP has begun with substantial changes in support mechanisms and schemes mainly aimed at reallocating funds to small farms and extending the scope of green policies This changed institutional environment is a challenge for both the beneficiaries of the CAP and the administration of the Ministry of Agriculture and Food (MAF) and the State Fund for Agriculture (SFA).

Substantial changes in CAP direct payments schemes 2014-2020 will affect the restructuring of Bulgarian agriculture in the following areas: redistribution of income from the larger to the smaller farms; Increase in costs due to introduction of diversification of the production structure; missed benefits of restrictions on intensive use of ecological and grassland areas.

In the context of the new agricultural policy, the CAP 2014, modified in response to the environmental sensitivity of society, an introduction of a number of measures aimed at 'green' production is to be done.

This change will lead to a relative narrowing of the grain production share in the final economic results of the plant growing and the expansion of the share of the other crops for which Bulgaria has comparative advantages.

\section{CONCLUSION}

On the basis of the retrospective analysis of the trends in the restructuring of Bulgarian agriculture several conclusions can be summarized:

- plant production has a leading share in comparison with livestock farming in the structure of our agricultural production;

- a bipolar agricultural structure is formed - on the one hand a small number of big farms specializing in the production of grain and industrial crops, and on the other - a large number of small farms whose production is mainly used for their own consumption;

- there is a steady trend in reducing the number of farms and their agglomeration;

- changes in the CAP 2014-2020 will affect the increase in incomes on small farms as a result of the redistributive payments introduced.

Restructuring in Bulgarian agriculture has not finished yet. A positive trend is to increase the level of specialization of farms by investing in new technologies and ameliorating the breeding improvement work and the gene pool.

\section{REFERENCES}

1. Agrarian report (2010-2016)

2. Chavas, J. P. (2001). Structural change in agricultural production: Economics, technology and policy. In Handbook of agricultural economics, Gardner B. and G. Rausser (eds.): 263-285, Elsevier.

3. Herck,N, Noev, J.Swinnen, 2011, Institutions, exchange and firm growth: evidence from Bulgarian agriculture, ER of Agricultural Economics pp 1-22

4. Kopeva, D. 2012, Land Relations at the Beginning of the 21st Century. Rakurs Publishing house, Sofia

5. Koteva, N. and al., 2015, Research and evaluation of the intra-sectoral restructuring of agriculture, EIA, CA

6. Koteva, N. and al., 2015, Trends in the Restructuring of Agricultural Farms, EIA, CA

7. Kaneva K. et al., 2016, Opportunities for development of farms in the conditions of the CAP 2014-2020, EIA, CA

8. Mitkova, D., B. Ivanov, 2013, Livestock breeding under the conditions of the implementation of CAP, EIA, CA,

9. Nikolov, D. et al., 2010, Impact of the CAP on the structural adaptation of agricultural farms, Journal of Economics and Management of Agriculture, issue 2,

10.Petrova, N., 2017, Land relations and structural changes in Bulgarian agriculture, International Scientific Conference, Management and Sustainable Development, University of Forestry, Yundola

11. Statistical Yearbook (2000-2016)

12. Yovchevska, Pl., 2014, Structural changes in the cereal sector of the Bulgarian plant growing (after implementation of the Community agricultural policy), Economics and Management, yearbook X, №1, Institute of Agricultural Economics, Sofia 